\title{
Contracting Out Services in the Nigerian Local Government: Implications for Internal Revenue Generation
}

\author{
Johnson Emeka Nwofia ${ }^{1}$ \\ ${ }^{1}$ Social Sciences Unit, School of General Studies, University of Nigeria, Nsukka, Nigeria \\ Correspondence: Johnson Emeka Nwofia, Social Sciences Unit, School of General Studies, University of Nigeria, \\ Nsukka, Nigeria.
}

Received: May 18, 2018

Accepted: June 30, 2018 Available online: July 4, 2018

doi:10.11114/ijsss.v6i7.3411

URL: https://doi.org/10.11114/ijsss.v6i7.3411

\begin{abstract}
The primary reasons for creating the Nigerian local government system was grassroots mobilization and development. The Council has however, consistently failed to provide critical services to the rural poor ostensibly because of poor funding. The work examined the structure, functions and accountability mechanisms of the Council vis-à-vis its revenue generation capacity. The problem identified is that the Council contracts out services and its statutory revenue sources at ridiculous prices to patrons even in the face of fiscal cutback and burgeoning demand from the critical populace. Using the Local Government Discretion and Accountability Diagnostic Framework of Analysis and Financial Agency Theory, the paper found that lack of political, administrative and financial accountability mechanisms provides the leeway for unscrupulous Council officials to grossly enrich themselves and their patrons. The paper recommends that the Public Procurement Act which emphasizes Due Process in tendering should be institutionalized by the local government. The anti-graft agencies should be repositioned to deal with treasury looters while the electoral process should be reformed to make it more transparent and inclusive.
\end{abstract}

Keywords: local government, local government system, council, internal revenue, contracting out

\section{Introduction}

The 1976 Local Government Reform and the 1999 Constitution of the Federal Republic of Nigeria (as amended) devolves some duties, responsibilities and empowers to the local government Councils. These include the powers to initiate development projects and deliver social services to people living in the rural areas. The implication is that the Local Government requires substantial funds to provide such critical services. In line with this, the constitution provides for internal and external sources of revenue to enable the local government to accomplish the statutory obligations.

The external sources include allocation from the Consolidated Federation Account, loans and grants. The Local Government also has Internally Generated Revenue (IGR) sources deriving from service charges, fees, levies and taxes. However, the local government has consistently failed over the decades to perform above board ostensibly because of fiscal constraints. The clamor is that the local governments need more funds to enable it perform better. It is argued, however, that most statutory services that represent the very essence of the system and which are veritable sources of internal revenue are contracted out not necessarily for its beneficial value but for selfish ends. The development has a number of implications. It calls to question the intentions, appropriateness and logic that drive contracting out in the Nigerian Local government vis-a-vis the prevailing global best practices and standards. It is curious that juicy revenue sources are contracted out for ridiculous sums to clienteles, patrons and cronies as political pay-off instead of trade-off between productive and other economic efficiency concerns including the costs of contract administration. The conclusion is that corruption provides the motive force that drives contracting out and that it contributes significantly to the ineptitude in the Nigerian local government system.

\section{The Nigerian Local Government System}

The Federal government created States and Local Governments in an effort to decentralize some of its constitutional or statutory obligations. The idea was to accommodate the different shades of political, economic, social and cultural peculiarities and gradations of Nigeria's multi-ethnic nationalities and their geographic characteristics. The 1976 Local Government reform established a uniform, single tier, all-purpose, grassroots system of Local Government Nigeria and squarely assigned to it the task of rural development (Ezeani, 2006). 
The import is that the local government was created to catalyze balanced development, provide a broader platform for citizens' participation in local governance and to induce greater government response to local problems. Ideally, it serves as political and administrative structure that facilitates decentralization, national integration, efficiency in resource allocation and mobilization for grassroots development (Tolu \& Olagunsoye, 2010). In a broader sense, the local government is acknowledged as a critical and veritable instrument for the administration of efficient, effective service delivery and participatory, all inclusive development (Arowolo, 2005). It serves a number of functions. First, it is a feedback institution that articulates and relays the opinions and demands of the rural or grassroots people to higher levels of government. Second, it is a veritable organ for rural service delivery, promotion of democratic principles and political participation at local level. Third, it builds capacity for governance and mobilizes human resources for sustainable grassroots development by virtue of its strategic position (Adejo, 2003). For Olowu (cited in Uzuegbunam \& Nwofia, 2014) the local government is useful for a number of reasons. First, as a democratic institution, it allows for self-governance including the choice of who governs, participation in the decision-making processes, building capacity for citizenship and higher-level leadership. Second, it mobilizes resources for rural development. Third, it promotes good governance through accountable and transparent self-rule. Fourth, it provides platform or channel for claim-making on higher levels of government. Fifth, it fosters unity by reducing social discrimination and conflict. Sixth, it provides two-way channel of communication between local people and higher levels of government.

According to Khemani (2001), the local government is strategic for a number of reasons. First, it has better information of local conditions and how best to address them, being the closest to the grassroots people than other higher levels of government. Second, they are best positioned to harness resources in the locality and transform them into needed social services which are rendered to the poor across sectors of rural communities. In this context, good governance is of great essence. Third, the local government is best positioned to recruit workers who are familiar with the peculiarities of the local environment. This means that it provides employment opportunities with the associated improvement in social and economic well-being of citizens. Generally, the responsibilities of the local government include: (i). Planning and monitoring - providing the overall direction for the communities through long-term planning and development. (ii). Service delivery - providing a range of quality services such as public health and recreational facilities, maintenance of local road, public libraries boreholes, electricity, etc. (iii). Lawmaking and enforcement - legislation and making decisions in areas over which they have legislative authority. Byelaws must not conflict with or be inconsistent with state and federal laws. Local governments are responsible for enforcing the byelaws and other legislation over which they have authority. (iv). Policy development - policies, like roadmaps, shows what the local governments wants to do, how to do them and the expected outcome. (v). Representation - The local government, by conception, is essentially democratic. The Council is representative of constituent local communities while policies and decisions on matters of concern are expected to be all-inclusive. (vi). Advocacy - Local governments have a role in advocating on behalf of their constituencies to state and federal levels of government, statutory authorities and other sectors. Fundamentally, the local government serves rural communities by mobilizing and harnessing local resources and ensuring their effective utilization superintended by the state and federal governments. Functions of the Local Government:

The 1979 and 1999 Constitutions (as amended) devolved more statutory functions and provided specific sources of revenue to the local government. Egbe (2014) posit that the devolution of specific duties and responsibilities, which are essentially service delivery, positions the local government at the forefront for rural development. Perhaps, this informs the status of the local government as a distinct single-tier, all-purpose administrative structure with neither sub- nor super ordinate appendages.

According to the 1999 Constitution, the Local Government Councils have the constitutional obligation to perform all the exclusive duties and responsibilities outlined in its Fourth Schedule. They include:

(i). economic planning and development;

(ii). maintenance of cemeteries, burial grounds, homes for the destitute and infirm, markets, motor parks, sewage and refuse disposal; street lighting, drainages, slaughter houses, public conveniences, other public facilities;

(iii). collection of community taxes, rates and licenses such as radio, television, bicycles, trucks (other than mechanically propelled trucks), canoes, wheel barrows, carts, tenement fees, control and regulation of outdoor advertising, liquor, etc ; collection of fees on shops and kiosks, bakeries, restaurants and eateries, laundries;

(iv). construction and maintenance of roads, street lightings, drains, recreation parks, gardens, open spaces; streets and naming of streets, roads, house numbering; and maintenance of other public facilities; registration of births, deaths, and marriages; regulation of pets.

(v.) the State House of Assembly may also prescribe or assign specific functions to the local government from time to time. (vi). the local government, in concurrence with the State government, also has responsibility for the provision and maintenance of primary, adult and vocational education; development of agriculture and natural resources (other than 
mineral exploitation) and health services. The tasks require enormous funding considering the fact that a greater proportion of Nigeria is essentially rural and that a greater percentage of Nigerians live there.

Consequently, the 1979 Constitution provides for other sources of fund in addition to the internally generated revenue. Specifically, section 7 (6) provides that the National Assembly shall make provisions for statutory allocations of public revenue to the local government councils in the federation. The House of Assembly of each state shall also make provision for statutory allocation of public revenue to local government councils within the state. This implies that each local government has the following sources of revenue: i. statutory allocation from Federal government ii. statutory allocation from the State government. iii. internally generated revenue. iv. grants and loans.

By an Act of the National Assembly, the 774 local government Councils in Nigeria are jointly entitled to $20 \%$ of monthly accruals to the Federation Account while each State shares 10\% of their internally generated revenue to the local government Councils in that State (Ezeani, 2004). Before the economic recession, the Councils also benefitted substantially from the Excess Crude Account and more recently, the Paris Club refund.

The local government system, as presently constituted, faces some challenges. They include hollow and inconsistent policy horizon, poor financing, bureaucratic corruption, political and economic interference and lack of autonomy, poor staffing and lack of technical expertise, poor governance, poor work ethics, etc. (Eboh \& Diejomaoh, 2010; Tolu \& Olagunjoye, 2010; Coker \& Adams, 2012; Adeyemi, 2013; Agba, Akwara, \& Idu, 2013; Ibok, 2014; Bolatito \& Ibrahim, 2014; Chukwuemeka et al., 2014).Generally, wide-scale fraud, embezzlement, inflated and abandoned contracts, etc. combine in various forms to vitiate the attainment of the objectives of the local government.

The assignment of specific functions and provision of sources of revenue have implications the primary of which is that the Councils, as autonomous entities, have the paraphernalia for public financial management. The argument that the councils have very limited and circumscribed sources of revenue with which to execute the functions and responsibilities meaningfully and effectively is secondary. Some local governments are essentially rural and without strong internal revenue base. The indigent populace is in dire need of critical but elusive social services. The Councils depend almost entirely on federal transfers accruing mainly from oil revenue with its attendant risk of external shock due to price fluctuations, poor accountability and macroeconomic instability. This predisposes the Councils to growing fiscal cutbacks, deficits and other budget constraints. Secondly, the inter-governmental fiscal arrangement is inconsistent with the autonomous status of the local government thereby undermining its essence as a sub national government (Khemani, 2001; Enemuo, 2005; Ezeani, 2012; Iwundu, 2012; Odalonu, 2015). The problem identified is that the current formula gives more revenue to the Federal and State governments rather than to the Local Governments that have greater base and responsibilities for the provision of social welfare to the people. The arrangement stifles the sub national governments' ability to provide social welfare and accomplish other statutory responsibilities. It also aggravates crises of relative deprivation, accentuates corruption and intensifies ethnic politics. The superior position of the federal and state governments reduces that of the local government to the level of subservience especially in terms of revenue generation and expenditure.

It has however, been argued that the local received substantial amount of money from the Consolidated Federation Account over the decades when the price of oil was high in the international market (Nwofia, 2017). According to Central Bank of Nigeria (2016), the 774 Local Government Councils in Nigeria received revenues from various sources amounting to N15.3 Trillion between 1993 and 2015. It spent N11.4 Trillion on recurrent expenditure while the capital expenditure was N3.9 Trillion painting a picture of consumption economy. It is worrisome that the local government failed to invest on productive and strategic poverty reduction programs and to develop critical infrastructures that provide social services. The structure of public expenditure implies that the Local Government annual budgets targeted consumption and handouts rather productive economic investments. One glaring point is that the local government failed to make corresponding impact on the masses when the huge sum disbursed to the Councils is compared to the achievements on the ground. The import is that the local government has not been able to provide the much needed development across the nation. It has been dispensing rural poverty, rather than rural development. The prevalence and pervasiveness of poverty and underdevelopment at the grassroots level is not unconnected with poor governance exemplified by the high level of corruption and impunity (Odalonu, 2015).

The poor performance is attributable to the failure of political actors to imbibe the noble ethos of democracy. Democratization at the grassroots lacks the three essential features of government outlined by Diamond, Linz, and Lipset (1989). First it does not involve meaningful and extensive competition among individuals and groups for positions of power at regular intervals. Second, it is highly exclusive of political participation in the selection of leaders and policies while election are sheer charade and unfair often with despicable outcomes. Third, it inhibits rather than promote high level of civil and political liberties and freedom. The situation is an abnegation of the noble conception of democracy as highly accountable and people-centered which underlie Ake's (1991) conception of its principles to include public 
accountability, widespread participation, and the consent of governed. The question that easily comes to the discerning mind is "What accounts for the Local Government's ineptitude?

\section{Organizational Structure and Accountability in the Local Government Council}

The Local Government has two arms namely the executive and the legislature (Ezeani, 2004). The executive consists of the Chairperson, Vice Chairperson, Appointed Supervisory Councilors and Council Secretary. The Supervisory Councilors are appointed by the Executive Governor of the State. The Chairperson of the Local Government Council is the Chief Executive and Accounting Officer of the Council. The legislative arm of the Local Government Council is constituted of the leader of the Council and other elected Councilors. Theoretically, the organizational structure of the local government consists of the following:

(a). the administrative structure which consists of the Executive Chairman, Secretary, Supervisory councilors and Heads of Department. Heads of Department are career civil servants who are now appointed by the State Governor.

(b). the financial structure which consists of the Treasurer and Auditor of the Council.

(c). the committee structure which consists of the financial and general purpose, police and community relations, education, works and housing, health and environmental services, agriculture, rural and social services, financial and economic planning committees.

(d). personnel structure is superintended by the Head of Personnel. The personnel department is responsible for all Council employees and acts in liaison with the Local Government Service Commission which is superintended by the State government. The Commission is responsible for staff recruit and discipline (senior cadre), welfare and training.

The Executive Chairman, as the Chief Accounting Officer is expected to comply with the extant byelaws, ordinances, edicts, laws, civil service rules, financial regulations and instructions on public funds and assets management. These are complemented by other internal control mechanisms. He is subject to periodic checks to ascertain the extent of compliance with financial control and management mechanisms as a chief executive and accounting officer. The chairman renders monthly statements of income and expenditure to the Council. He also presents annual reports in the form of performance-based budget to the Council accounting for income receipts and expenditure, outlining achievement and activities for the past year. He also makes financial projections, sets targets to be achieved and activities for the coming year. The Chairperson renders quarterly returns of the actual income and expenditure of the Local Government to the Office of the Vice-President of the Federal Republic of Nigeria and the Central Bank of Nigeria through the State Government.

The Legislature comprises the leader of the council (Speaker), the Deputy Leader and elected Councilors. The legislative powers that the Council exercises are the byelaws passed by its legislature with the assent of the chairperson. The byelaws border on matters in the exclusive list in the fourth schedule of the 1999 constitution. Federal and State laws especially those bordering on the concurrent lists supersede the byelaws. The Legislature makes resolutions and approvals and has the powers to impeach the Chairperson of the Council or the Speaker by a two third majority over serious issues such as abuse of office. Furthermore, the legislature confirms the appointment of Supervisory Councilors or the nomination of Vice-Chairperson in the event of vacancy because of death, resignation or removal. The possibility of the Council Legislators rejecting or refusing to confirm the Supervisory Councilors that are appointed by the State Executive Governor remains in doubt. More so, the Supervisory Councilors, once confirmed, are superior to the elected Councilors.

The Supervisory Councilors are politicians and patrons appointed as heads of distinct departments and they superintend over career civil servants and technocrats. They are members of the Finance and General Purpose Committee and by implication, members of Local Government Executive. As political office holders, they issue directives and instructions to proximate officers who are career civil servants and heads of their respective departments on general policy issues but not necessarily on the internal management of the department. The arrangement has some implications. First, the Supervisory Councilors often lack the requisite experience, expertise, skills and competencies on administrative and policy issues concerning the Departments. This makes them to depend on the expertise of the career officers who in turn, try to call the shots. This is usually a potential source of conflict of interest due to struggle for the exercise of power and control. While the political appointees try to maximize opportunities for self-enrichment which is the underlining reason for the appointment, the career officers also indulge in corrupt enrichment.

Apart from the attrition, the arrangement makes it possible that select politicians (Executive Chairman, Vice-Chairman and Supervisory Councilors) who have short-term interests superintend over public resources. The poor framework for accountability makes executive rascality possible. Apart from the ritual of annual budget approval, the Legislature virtually has no other means of checking the excesses of the Executive unless by threat of impeachment. In such circumstances, the threats are diffused when part of the loot are dangled like carrots before the legislators. Since the bulk of local government revenue comes from federal allocation through the State Joint Local Government Account, it 
is easier for the Executive Chairperson to spend public funds without recourse to the financial regulations. It is not surprising that the Council payroll is usually over bloated with the names of family members and relations of politicians who draw money from public treasury as "ghost workers". The situation accentuates non-transparent, clientele transactions, patronage politics, policy subversion and lack of accountability.

By statute, the Supervisory Councilors also assist the Chairperson to supervise Local Government projects including contracts within their respective departments. They also chair the committees of their respective strategic departments namely Education, Works, Health, Agriculture, etc). These are critical areas that beckon for sustained and prudent management. The arrangement also has implications. The politicians who have no long-term commitments and the requisite or cognate experience superintend over professionals, career civil servants with technical competence and expertise. Consequently, the Local Government has transformed to distributive arenas where money and contracts are shared out to identity groups and patrons. Contemporary analysts attribute the ineptitude of the local government to limited financial autonomy and mismanagement, corruption, lack of accountability and transparency, political interference, meddlesomeness among others (Coker \& Adams, 2012; Odalonu, 2015).

\section{Statement of the Problem}

The Nigerian local government is saddled with the responsibility to provide effective and efficient social services. The rational mobilization and utilization of resources for the accomplishment of the goals borders on good governance. As a bureaucratic organization, the Local Government has employees with requisite technical expertise at its disposal and statutory internal and external sources of revenue. Hitherto, the major argument to justify the failure of the Local Government to mobilize for rural development has been that the funds available are too meager compared to the enormous responsibilities. Conversely, the question that comes to mind is 'what achievements have the local government on the ground to account for the much that has been at its disposal?' It is curious that the system has not achieved much in terms of development despite the enormous allocations from the federal and State governments in the past decades when the price of oil was high and stable.

According to Central Bank of Nigeria (2015) cited in Nwofia (2017), the 774 Local Government Councils in Nigeria received revenues from various sources amounting to N15.3 Trillion between 1993 and 2015. The recurrent expenditure for the period is N11.4 Trillion while the capital expenditure is N3.9 Trillion. This implies that the Local Government annual budgets targeted consumption and handouts rather productive investments and infrastructural development. Some Local Government Councils shamelessly borrowed from commercial banks to finance consumption with the active connivance of the superintending State Governments. In this context, the looted funds form part of the consumption since they do not possess any tangible productive value. Paradoxically, most statutory services that are revenue yielding are contracted out as patronages to political cohorts at ridiculous costs. The contractors, in turn, charge higher sums of money from hapless citizens for poor quality services.

Before now, the Local Government maintains in-house equipments and personnel with the requisite technical expertise in construction of roads, buildings, drainages, boreholes, waste management, etc. The current trend is that the Local Government prefer to award contracts to businessmen at highly inflated costs. Worse still, since the contracts are not based on merit or expertise, they are either executed shoddily or abandoned. Above all, such contracts are highly inflated, sometimes unfeasible and awarded in nontransparent, unaccountable manners and without recourse to due process in public procurement. The obvious realization is that the motive force that drives contracting out in the Local Government is pecuniary gains. The question is why should internal revenue sources, which are expected to be harnessed and used rationally by the local government Council to provide needed social services to the critical poor masses be given out as contracts or pay-off to patrons? This paper further examines the logic of contracting out using international best practices as benchmark in relation to what obtains in the Nigerian Local Government.

\section{Conceptual Explication of Contracting Out}

The common reason adduced for contracting out services by the Local Government is that it is increasingly becoming an acceptable response to fiscal constraints. The increasing demand for social services by communities, rapidly burgeoning population, urbanization, desire for increased quality of service and other factors combine in various forms to confound the Local Government service obligations. Ideally, transferring services statutorily assigned to the Local Government to private individuals, companies and corporate bodies promises the potential of increasing efficiency at less cost.

Contracting is the mechanism that enables the local government to acquire specified quantity and quality of services at an agreed-on price from a specific provider for a specified period (OECD, 2011). Contracting out or outsourcing is the use of private companies (profit or nonprofit) to provide public services (Ohio Civil Service Employees Association, 2013). As an aspect of privatization, it seeks to shift jobs and service delivery to the private sector based on the philosophy that companies can always perform better than public workers. Contracting out refers to provision of 
services which are rendered statutorily by the local government but which are undertaken by external suppliers on agreed terms. It is a 'make-or-buy' idea implying that the local government can provide the services with their own employees or choose to contract out to private or public sector providers. This may be driven by a number of factors. First, it may be a trade-off between productive efficiency and the cost of bureaucratic administration due to weak incentives to employees. Second, it may help to reduce or avoid high transaction costs such as when heavy duty or specialized equipment is required. Third, it may serve as private benefit to politicians by keeping the service provision inside the government (Levin \& Tadelis, 2010). Contracting out is an agreement by which the local government (purchaser) provides payment to another party outside of the government (provider) in exchange for a definite set of services for a specific target population (OECD, 2011). Contracting in is where the Federal or State government contracts with the local government for the execution of specific services on agreed terms and conditions. This happens when the local government is best positioned to carry out such tasks although it is the statutory responsibility of a higher government.

Abramson (2011) further define Performance-Based Contracting (PBC) as transfer of competencies for a defined period of time based on formal agreement (contract) whereby payment is made by a local government to a contractor (provider) based on the attainment of predetermined results. In other words, payment is contingent upon concrete and measurable criteria or achieving a predetermined target with rewards for reaching or surpassing targets. This makes it that contracts should include a variety of indicators to measure performance. The Commonwealth Management and Training Services Division (1994) posit that contracting out permits a private sector contractor to assume responsibility to provide a specified level and quality of public services for a fee based on agreement. The objective is to obtain the most cost effective delivery of the service using competitive tendering, from public sector organizations and entrepreneurs. The contract clearly specifies the type and quality of service desired and the mechanisms to monitor progress.

Contracting out can serve a number of purposes (Domberger \& Jensen, 1997). First, it can serve as instrument for strengthening performance of the government. Second, it can serve as the means to provide essential public goods and services. Third, it formalizes relationships between the government and private service providers for delivery of public goods, services and functions. Fourth, it can be cost effective especially when there are economies of scale. Fifth, by providing efficient services, it instills citizens' confidence and trust in the government. Contracting out is suitable where there is weak infrastructure and low capacity of government, high cost of service provision, low socio-economic status of the target population; lack of confidence in services provided by the government. Others are high levels of social and economic inequity, gaps in access to essential services, disparities between the rich and the poor. Since it has proviso for specification, regulation, sequential financing, etc, it helps the government to maintain ownership and oversight when contracting out to private providers.

The proponents of contracting out posit that resource allocation is more efficient in the private sector and that it has the potential for optimal output at minimum production cost (Domberger \& Jensen, 1997; Levin \& Tadelis, 2010). The public service, by its monopolistic nature, is non-competitive, non-innovative, wasteful, and inherently inefficient. The argument is that contracting out infuses openness and accountability in the public procurement process particularly in pluralistic societies where every phase must balance with social, economic and political objectives of the local government.

The bureaucratic structure of the Local Government has framework for managing public finances and assets. It has the responsibility to balance the private interests of the service providers through leadership in setting policy and oversight. Ideally, contracting out should help the Council to ensure fiscal discipline by prioritizing its revenue and expenditure options. This is because contracting out is a flexible method for private sector participation in the provision of efficient and economical services. By being competitive and regulative, it should help the local government to ensure transparency in procurement processes. The proposition therefore, is that contracting out helps the local government to adopt competitive, business-like approaches by exposing public sector activities to market mechanisms in ways that optimize the benefits while mitigating the shortcomings (Amagoh, 2009). As a model it presents a clear set of empirical basis for the analysis and prediction of contracting outcomes since it is a trade-off between productive inefficiencies that arise from using salaried employees and the costs of specifying and administering more productive performance contracts (Levin \& Tadelis, 2010).

However, the American Federation of State, County \& Municipal Employees (2015) argues that contracting out often results to higher costs, poorer services, increased opportunity for corruption, and diminished government flexibility, control and accountability. It can also compromise the security of public assets. It undermines the local tax base and employment opportunities for citizens when contracts are awarded to companies that are based outside the local area. Skilled employees might be rationalized or crowded out since contractors prefer to use low wage, no benefits workers as cost-cutting measure. Overdependence on contractors makes the government susceptible and vulnerable to gouging or overcharge on public treasury. Since some public services are fluid or not easily packaged, and without clear 
boundary, it is extremely difficult to clearly state and evaluate the terms of contract. The question becomes 'How do you assess or benchmark non-packageable public goods?' Ambiguity and lack of clarity in contracts create room for irregularities, extortion and substandard services. While it may be expedient to politicians because of its popularity, it is a conduit for pay-offs to political supporters and patrons; and for the corrupt enrichment of Local government officials. It also helps officials to sideline labor unions, circumvent the law and downplay the workforce. The World Bank (2004) noted that contracting out distorts the framework of relationships for accountability between citizens, contractors and the public policy makers. Contracting out implies market transactions without direct accountability of the service provider to the public. Though the local government may have the contract management responsibility, it is sometimes difficult to control the service provider especially where the decision makers lack requisite technical expertise and knowledge.

Stokes cited in Slot (1998) identified three forms of contracting out namely competitive tendering, management contract and build-operate-transfer schemes. The competitive tendering involves the provision of specific public services or activities such as waste collection and disposal; while management contract occurs when private sector management takes over business operations, maintenance and possibly investment responsibilities for facilities owned by the local government. Its variants are lease agreements, concessions and privatization. Lease agreements and concessions allow the local government to own the assets while privatization passes asset ownership to the private sector. In Build-Operate-Transfer (BOT) schemes, private sector consortiums finance, build, operate and transfer ownership of infrastructural projects. Another form of contracting out is management buy-outs where managers or employees of the enterprise acquire controlling shareholding in the enterprise. For instance, strong labor unions may secure loans using the company's assets as collaterals.

From the foregoing, contracting out offers veritable alternatives backed by private sector capitalization, management capacities and technical skills that translate to efficient and cost effective social services. It is agreeable that one of the major challenges of the local government is the inadequacy of funds ostensibly because of mismanagement and that contracting out ideally, offers credible alternatives to the accomplishment of the objectives at lower costs. As change management tool, it should be used to respond effectively to emergent responsibilities to constituents and sustain service delivery in unique and innovative ways. Expectably, contracting out enhances service delivery and distributive equity. It is arguable that services delivered through contracts can be more effective than publicly provided services. It also helps the government to link expenditures to performance objectives by defining specific results that are reflective of the public sector's policy objectives.

\section{Criteria for Contracting Out}

It has already been pointed out that contracting out, being an aspect of public procurement, is susceptible to corruption and other forms of abuse. Apart from the need to adhere strictly to the due process mechanism, certain other principles must be observed (Ascher, 1987, United Nations Human Settlements Program, 2015). They include:

(i). Prioritization of the services to be provided, who beneficiaries are (the cue bono principle) and the framework of accountability between the people, government and service provider;

(ii). The feasibility and sustainability of the projects must be assured;

(iii). the contract terms must be equitable as to cover the entire service area and providers must adhere to sound environmental principles;

(iv). Service providers must possess the requisite technical expertise and capacity to execute the contract;

(v). Employees interests that essentially border on labor issues and other negative social impacts or externalities must be mitigated;

(vi). the procedures and processes for public procurement must be open, transparent, competitive, accountable and cost effective with predictable outcomes;

(vii). performance of service providers must be monitored by the local government as the custodian of the peoples' interest while service providers must be responsive to the needs and problems of customers;

(viii). Contract decisions must involve all stakeholders who will be affected by the outcome but the buck stops with the Local Government chairman.

(ix). Payment of contract fees should be based on specific performance benchmarks to avoid substandard or shoddy services and project abandonment. There must be proviso for recompense in the event of the contract being abandoned.

Furthermore, services to be contracted out must be quantifiable and executable (Marlin, 1984). Fyklund cited in Slot (1998) outlined six basic rules for contracting out if the local government is to get the best out of the deal. First, it must be a response to a specific problem. Second, it must be cost effective, that is, the direct and indirect costs of providing 
the service by the local government must be higher than the cost of providing the same service by the private sector. Third, services are not to be contracted out unless the expected gains exceed the transaction costs. Fourth, public policy analysis must be properly conducted to determine possible externalities and other implications of contracting out. Fifth, the real benefits of contracting out come from the complementarities and underpinnings of the private sector partner's resources and expertise. There is no need for contracting out when the local government has the capability to provide the service efficiently and cost-effectively. Sixth, government can never contract away blame or responsibility. The buck stops with the decision-makers.

The House of Commons (2014) also outlined some criteria for contracting out. First, the contract must protect taxpayers' interest and legitimate expectations. Second, the contract terms must be standardized. Third, there must be clear information about the contractors to determine their capability, honesty, integrity and credibility. Fourth, public service standards must be maintained. Fifth, Public officials who monitor contracts must possess sufficient authority, skill or expertise. Sixth, there must be effective governance and internal control of contractors by relevant departments.

\section{Diagnostic Theoretical Framework}

Based on the foregoing, it is necessary to look at the accountability mechanism as defined by the structure and functions of the local government. The idea is produce a framework within which to understand the underpinnings of the system of accountability and to use it to weigh the standard of practice of contracting out in the local government. The structure defines the nature and inter-relations of the individuals and groups who carry out the various functions of the local government. It defines lines of authority and responsibility with regard to decision-making and control. Two theoretical viewpoints are used for the work. They are the Local Government Discretion and Accountability Diagnostic Framework of Analysis (Yilmaz, Beris, and Serrano-Berthet, 2008) and Financial Agency Theory (Bruce, 2005).

The Local Government Discretion and Accountability Diagnostic Framework of Analysis (Yilmaz et al, 2008) examines the relationship between decentralization, accountability and governance. The framework posits that as a sub national government, the local government can assessed based on the extent of decentralization, the accountability mechanism and the governance outcome. Through decentralization, some powers were devolved to the autonomous tier to provide specified services, raise revenue and provide policy directions. This required mechanisms for internal checks and balances that are underpinned by independence and political, administrative and social accountability. The political independence relates to the discretion to make decisions and implement decisions while being accountable for the fallouts. The objective is to evaluate the extent the present structure enables the Council to accomplish its statutory responsibility for good governance.

The political accountability context examines the extent of transparency of the electoral process, the extent of participation and inclusiveness of all relevant stakeholders, oversight and other control mechanisms, etc. Administrative accountability ensures that rules and regulations that guide human, financial and other resources management processes are properly mobilized and utilized. Social accountability assures goodwill, commitment and acute sense of responsibility in the provision of public goods and services. In summary, while political and administrative accountability form part of the structural and functional relationships, social accountability represents the role of the people as active participants in governance and the knowledge of how their affairs are run. A properly informed electorate is empowered to evaluate the leadership performance and to make informed choices while choosing future officials. The principles are encapsulated in good governance which is the pivot for rural mobilization and development.

The framework lays emphasis on the nature and extent of political, fiscal and administrative devolution and how it affects the independence, viability, accountability and social responsibility functions of the sub-national government which is in-turn expressed as the aggregate local governance outcomes. As an expository analytic framework, it provides the discretion for political office holders to make decisions on how to apply scarce resources in the most rational and transparent manner, monitored by the citizens with mechanisms for empirical evaluation of outcomes. Ideally, it underpins the efficacy of the Council's political, fiscal and administrative responsibilities backed by sound economic planning and decision-making which results to predictable development outcomes.

\section{Financial Agency Theory}

Agency theory explains the relationship between a principal and an agent in a transactional partnership. Usually, the principal contracts an agent to perform a task which the principal is unable or unwilling to do (Bruce, 2005). Naturally, the agent as a human entity has his compulsive personal interest or advantage to pursue. The agreement or contract spells out the goals or terms which naturally, are substantially if not solely tailored to suit the interest of the principal. But the agent pursues self-interest objectives that are diametrically opposed with those of the principal. Each party therefore, tries to maximize his own self-interest. The problem is how to resolve or transform the ensuing conflict of interest or values. 
Principal-agent theory is less concerned with whether a service is delivered through a public or a private organization. Its main focus is on the dilemma of how to make an agent act in the interest of the principal. The assumption is that asymmetric information between the two parties, risk aversion on the side of the agent, uncertainty, and a divergence of the agent's goals from those of the principal are sources of conflict. Agency theory aims at developing governance structures that attenuate this trade-off. Financial agency theory in organizational settings provides the means of assessing an agent's work for a principal (Pava, 2009). It captures the costs and benefits of the principal-agent relationship especially when public officials and other private individuals put their own interests ahead of public's interests. The analyses of agency costs are a common managerial tool to determine whether or how well officials fulfill their fiduciary obligations to the public vis-à-vis the resources available. The theory describes the agency relationship as a contract (explicit or implied) in which the principal (e.g. the Executive Chairman) hires the agent (Contractor) to perform some specific action. The principal formally delegates decision-making authority to the agent.

Agency theory helps to propose specific and testable empirical hypotheses such as questions about externalities, the ethical assumptions that underlie contracting out, and the social costs associated with private dishonesty. In the public realm, the self-interested behavior of public officials and private contractors weigh against the collective social impact of their behavior on the constituents. Organizational behavior encompasses the divergent interests of the principal (the relevant public) and agent (the contractor) and the limitations on the principal's ability to fully observe agents' actions. Agency theory is a tool for analyzing and understanding the economic choices and behavior of economic actors in the public and private sectors in which cooperative behavior is necessary to achieve a desired goal. The challenge therefore, is the possibility for the agent to either forego the self-interest or work in a way that maximizes his personal benefit and that of the principal. The problem of moral hazard can be mitigated through outcome-related or performance based payments, increased transparency of information by benchmarking and monitoring; and control by ensuring adherence to rules and regulations. However, extensive rules and regulations may impair flexibility and a focus on outcomes rather than processes, which motivated the transaction in the first place. The proposition is that a standard of agency responsibility is necessary irrespective of the agent's selfish motive. The agent has a moral responsibility for his actions that cannot be dismissed simply on the basis that he acts as an agent for the principal.

\section{Application of the Theories to the Nigerian Local Government}

The principle that drives every open society is the involvement of the citizens in determining their collective will or objectives. Though the approaches differ, the electoral system remains the potent and legitimate way to choose those who represent the different shades, segments or interests who articulates the diverse interests into one coherent whole. This requires strong, all-inclusive grassroots electoral systems that enable citizens to determine who represents them, the extent of inclusiveness, how pro-poor policies are, and opportunity to vote out non-performing and dishonest politicians. The local government has mechanisms for internal democracy. Ideally, the legislative (which constitute of elected Councilors) and the Executive arms provide the checks and balances. While the legislature approves budgetary expenditures, the Executive Chairman authorizes disbursements guided by extant rules and other internal control mechanisms. In reality, budgets are mere annual rituals since legislative constraints such as mandatory maximum expenditure threshold are brazenly abused. This makes the Executive Chairmen to operate like loose cannons and reduces the legislature to mere rubber stamp.

The administrative structure rests on the executive chairman, secretary, supervisory councilors and heads of department while the financial structure consists of the treasurer and auditor. The chairman, ideally, is an elected official while the secretary and supervisory councilors are partisan political appointees who have no long term stake in the Council. The treasurer, auditor and heads of department who are career civil servants, are card carrying members of the ruling political party.

In reality, the Councils depend almost entirely on monthly statutory allocations from the State Joint Local Government Account which is easily diverted for private ends by officials and their patrons. It is easy for the Executive Chairman to collude with other political appointees to award phantom contracts to dummy firms and to political patrons. The partisan career civil servants such as the treasurer, auditor and heads of department who ought to complement the internal control mechanism are 'settled' with monetary inducements. The consequences of graft are many. Some Council owes workers for months (up to one year or more) in arrears of salaries. This in turn accentuates self-gratification since employee revenue collectors devise means of stealing public money. The spill-over effects of corruption include un-cleared waste on the street, scarcity of portable drinking water, lack of electricity supply, poor roads, poor healthcare facilities, dilapidated schools, etc. Paradoxically, service delivery outlets from which revenues accrue are contracted out to rent-seeking political patrons, cabals and hangers-on as pay-off.

The scenario becomes clearer when the framework is juxtaposed against the basic tenets of the agency theory. Ideally, the Council and the contractor each has certain interests and consistently chooses those actions that are most likely to 
maximize his own expected utility. This means that both entities act in ways that promote their own self-interest. The situation is however, complicated by the fact that the Council officials who are supposed to act in public interest actually undermine such considerations to their own personal benefit or gain. The actions result to three types of costs that are inherent in all agency situations: the costs incurred by the Council to monitor the contractor's behavior; the costs incurred by the Contractor to guarantee the quality of his actions; and the monetary value of any loss in utility experienced by the Council that results from the Contractor's self-interested behavior. The deviation of the Contractor's interest from that of the Council is calculated as 'contract loss'. This is based on the assumption that the Council should make rational choices or decisions and take actions that confer maximum benefits to the people. It is therefore, the responsibility of the Council to anticipate that the Contractor will behave in self-interested ways by placing greater priority on actions that will serve his own interests rather than that of the Council as a proxy. To forestall this, the Council can take strategic steps to limit the damage caused by the agent's self-interested behavior by defining contract terms in ways that indemnify it. These may include provisos for rewards for good performance such as timely completion of contract and penalties for poor performance.

\section{Contracting Out in the Nigerian Local Government}

The local government, by constitutional provisions, occupies the centre-stage as a catalyst for grassroots development. There are concerns that the Constitution devolved a lot of responsibilities to the tier without corresponding provision for funding. Proponents argue that one serious consequence is the increasing annual deficits and insufficient funds for meaningful growth and development. Worse still, service obligations are on the increase because of burgeoning population while fiscal conditions are on the decrease. In the circumstance, contracting out project itself as a veritable cost-saving tool for exploiting economies of scale, reducing deficits, overcoming input rigidities and inducing incentives for efficiency. It can also help to overcome paucity of expertise or equipment such as heavy duty and specialized machines. The challenge is how to provide and sustain access to quality services and retain the patronage of the ever increasing population.

Curiously, contracting out in the Council negates the ideals (Marlin, 1984; Ascher, 1987; Slot, 1998; House of Commons, 2014 \& UNHSP, 2015). It is not necessarily driven by efficiency gains but by pecuniary considerations. This makes it susceptible to abuse by officials and explains the reluctance to follow procurement procedures. It is done in a number of ways. First, the Chairman may contract out quantifiable and non-quantifiable but chargeable service delivery to political patrons, friends and family members at give away prices. The money realized from such transaction are often not paid into Council coffers or treasury but embezzled by proximate officials. Since it is a business transaction, the contractor recoups the contract sum money and makes profit sometimes by offering poor and exorbitant services to the poor citizens. Second, the Council chairman sometimes award fictitious contracts to himself, members of his household, cronies, patrons and phantom contractors as a way of siphoning public revenue. In arch circumstance, fake receipts are used to retire the transactions in the account book. The contract may range from purchases of stationeries, furnishing or refurbishing offices, plants, machineries to maintenance of existing buildings and construction of new ones. Third, the Council may award contract for the construction or rehabilitation of roads, boreholes, buildings, etc. The contracts are grossly inflated and may be poorly executed or abandoned. It is common that roads for which millions of Naira of public fund has been expended to construct are washed away by the first rain of the year without questions or enquiries.

\section{Discussion}

It has already been identified that the local government system, as presently constituted, faces serious challenges. The effort at vertical and horizontal devolution of power was designed to decentralize development strides at the grassroots. To be effective, it needs to be underpinned by autonomy and independence in its political, administrative and social responsibilities. Unfortunately, the Council is generally overburdened by hollow and inconsistent policy horizon, poor financing, bureaucratic corruption, political and economic interference and lack of autonomy, poor staffing, lack of technical expertise, poor governance, poor work ethics, etc. (Eboh \& Diejomaoh, 2010; Tolu \& Olagunjoye, 2010; Coker \& Adams, 2012; Adeyemi, 2013; Agba, Akwara, \& Idu, 2013; Ibok, 2014; Bolatito \& Ibrahim, 2014; Chukwuemeka et al., 2014).

The structural-functional relationship among the officials of the Council is dysfunctional for a number of reasons, the primary of which is the fact that mechanism for accountability is weakly embedded (Nwofia, 2017). Democratic principles which are the bedrock of accountability in the local government, is a sham since elections are rarely free and fair. The chairmen and Councilors are either installed by political godfathers or are handpicked by the State Governor. Elections have been reduced to mere ritualistic absurdity. It is known that political office holders are often selected by powerful politicians rather than elected. The 'offices' are sometimes bought on the basis of the highest bidder. The poor are not only excluded from contesting for political offices because they cannot afford the high cost, they are also denied 
the opportunity to decide who governs them. By allowing civil servants to become card-carrying party members, partisanship now determines who occupies career positions in the Council. This means that appointments and promotions are based on political considerations and influence peddling rather than merit. Fundamentally, institutions that underpin sound democratic culture at the grassroots are lacking.

By bastardizing the electoral system, the poor are unable to hold the politician accountable for his actions and inactions at the polls. Instead, dishonest politicians with empty promises hand out ready cash earlier stolen by patrons and kingmakers to the poor in exchange for their votes. The campaign contributions are recouped when the local government is hijacked. The consequence is that the selected officials do not have the peoples' mandate but owe allegiance to their political godfathers and patrons. Public services and revenue becomes the currency of political patronage and monumental corruption. Since contracts are seen as pay-offs for identification and patronage, the costs are grossly inflated because of lack of adherence to procurement processes. Contract fees are sometimes paid in advance only for the contract to be abandoned midway, shoddily executed or not executed at all. Council officials even award contracts to themselves, family members and cronies sometimes using phony or dummy companies. The contractor as agent feels no moral responsibility or obligation to the Council because public money is perceived as part of the spoils of office. In the absence of strong internal control mechanism or control from higher levels, accountability is undermined while the governance outcomes actually accentuate poverty. Generally, the Council is characterized by a lugubrious picture of wide-scale fraud, embezzlement, inflated and abandoned contracts, etc. which combine in various forms to vitiate the attainment of the objectives of the local government

\section{Result}

The practice of contracting out has far-reaching implications. First, it short-changes the Councils of the much-needed Internally Generated Revenue (IGR) for rural development. Second, it provides easy money which is easily stolen by Councils officials especially the political office holders and other top officials. Third, it provides avenue to pay-off and enrich, privileged political patrons, clients and cronies at the expense of the public. The citizens are denied services that are critical for their survival. It fosters grand corruption and makes the local government susceptible for hijack or capture when public revenue is massively diverted to service the interest of powerful political patrons in a complex sinkhole of corruption. Fourth, it spurs conflict among the political class in the struggle for control of public offices and resources. Most importantly, it accentuates cyclic poverty and impoverishment because money for the provision of critical social services ends up in private bank accounts. Failure of the Council to provide critical services to the people erodes public confidence while accentuating apathy and indifference among the populace.

\section{Conclusion and Recommendation}

The local government was created as a sub national government with specific responsibilities and positioned to drive rural development. The Constitution provides for specific sources of revenue to enable it accomplish the tasks. As a democratic bureaucratic structure, it has mechanism for accountability. The local government has however, failed to provide critical services to the poor. Corrupt officials steal from the government treasury while internal sources of revenue are contracted out to political patrons for pecuniary gains. The result is increased poverty and underdevelopment. Thus, public institutions such as health centers, boreholes, schools, roads, sanitation, etc. are either lacking or inaccessible. The paper examined the meaning, essence and criteria for contracting out especially in situations of fiscal constraint.

When subjected to two theoretical frameworks of analysis, it is concluded that contracting out in the local government does not conform to prevailing standards or benchmark but is rather driven by corruption. This is accentuated by the weakly embedded mechanisms for public accountability. Based on the foregoing, the following recommendations are made:

(i). contracting out or outsourcing is a procurement process and therefore, should be tender-based and competitive. A Public Procurement Act should be promulgated by higher levels of government to establish a Tender Evaluation Board consisting of representatives from the executive, the legislature, secretary, treasurer, auditor and heads of departments to scrutinize contracts above Five million Naira thresholds. Contracts should not be awarded to local government officials or stakeholders with conflict of interest.

(ii). The Tender Evaluation Board should monitor and strengthen oversight of contracts by ensuring that payments are matched with performance. The Board is to ensure that contractors comply with the terms of the subsisting agreement and public sector probity standards.

(iii). Public procurement law regime reforms should be institutionalized at the state and local levels of government to entrench transparency, accountability, probity and zero-corruption in public procurement system. The Public Procurement law should spell out strategic contracting or procurement procedures especially the circumstances under 
which a Council can contract out its statutory functions and the conditions for such decisions. The Council should not contract out service areas where the scale of economies confers comparative or competitive advantage. The decision must involve the consent of relevant publics and stakeholders and not that of the Chairman alone.

(iv). Corruption is both venal and banal in the Nigerian local government system. The Council is perceived as a distributive arena rather than a training ground and launch pad for higher levels of responsibility. Unfortunately, Council officials who looted public treasury are foot loose and fancy free while the masses languish in abject poverty. This calls for the need to strengthen and institutionalize the anti-corruption strategies and the judicial system to prosecute and punish looters.

(v). There is need to reform the Nigerian local government system. The mechanism of political, administrative social responsibility accountability is too weak. The legislature, which ought to provide the checks and balances and curtail the excesses of the executive, is moribund giving the Executive Chairman near sweeping powers. Electoral reforms will also remove all vestiges of state government meddlesomeness or interferences, strengthen the electoral processes and make office holders accountable to the electorate.

\section{References}

Abramson, W. B. (2004). Contracting for health service delivery: A manual for policy makers. Arlington: USAID.

Adejo, O. (2003). Local government and the 1999 Constitution. In Kwanashie, M. (ed). Politics and Political Power Relation in Nigeria. Zaria: Dat and Partners.

Agba, M. S., Akwara, A. F., \& Idu, A. Y. (2013). Local government and social service delivery in Nigeria: A Content Analysis. Academic Journal of Interdisciplinary Studies, 2(2), 455-462. https://doi.org/10.5901/ajis.2013.v2n2p455

Ake, C. (1999). Rethinking african democracy. In Mimiko, D., Akanbi, A., \& Popoola, M. (eds.) Democracy and Public Administration in Nigeria. Akure: ABM Services Ltd.

Amagoh, F. (2009). Information asymmetry and the contracting out process. Public Sector Innovation Journal, 14(2), 2-14

American Federation of State, County \& Municipal Employees (2015). Government for sale: An examination of the contracting out of state and local government services (8th ed.) Washington DC.:AFSCME.

Arowolo, D. (2005). Local government administration in Nigeria: An insider view. In Owolabi, D. \& Aladegbola, A. (eds.) Local government studies. Akure: Excels Production.

Ascher, K. (1987). An introduction to contracting out. In The politics of privatisation: Public Policy and Politics. London: Palgrave. https://doi.org/10.1007/978-1-349-18622-8_1

Bolatito, S., \& Ibrahim, B. S. (2014). Challenges of Local Government Administration in Nigeria: An Appraisal of Nigerian Experience." International Journal of Science and Research, 3(7), 562-568.

Central Bank of Nigeria (2016). Annual statistical bulletin: Summary of local government finances. Abuja: Central Bank of Nigeria.

Chukwuemeka, E., Ugwuanyi, B. I., Ndubuisi-Okolo, P., \& Onuoha, C. E. (2014). Nigeria local International Multidisciplinary Journal, Ethiopia, 8(2), 305-324.

Coker, M. A., \& Adams, J. A. (2012). Challenges of managing local government finance in Nigeria. Journal of Research on Humanities and Social Sciences, 2(3), 1-13.

Commonwealth Management and Training Services Division (1994). Management of the privatization process: A guide to policy making and implementation. London: Commonwealth Secretariat.

Diamond, L., Linz, J., \& Lipset .S. (eds). (1989). Democracy in Developing Countries2: Boulder Lynne Reinner Publishers.

Diejomaoh, I., \& Eboh, E. I. (2010). Local governments in Nigeria: Relevance and effectiveness in poverty reduction and economic development. Journal of Economics and Sustainable development, 1(1), 12-28

Domberger, S., \& Jensen, P. (1997). Contracting out by the public sector: Theory, evidence, prospects. Oxford Review of Economic Policy, 13(4), Dec, 67-78. https://doi.org/10.1093/oxrep/13.4.67

Egbe, E. J. (2014). Native authorities and local government reforms in Nigeria since 1914. Journal of Humanities and Social Science, 19(3), March, 113-127. https://doi.org/10.9790/0837-1935113127

Enemuo, F. C. (2005). Decentralization and local government: models, principles and purpose. In Anifowoshe, R. \& Enemuo, F. C. (eds.) Elements of Politics (pp. 311-326). Lagos: Sam Iroanusi Publications. 
Ezeani, E. O. (2004). Local government administration. Enugu: Zik-Chuks Publisher.

Ezeani, E. O. (2006). Fundamentals of Public Administration.Enugu: Zik-Chuks Publisher.

Ezeani, E. O. (2012). Delivering the goods: Repositioning local governments in Nigeria to achieve the Millennium Development Goals: 66th inaugural lecture of the University of Nigeria. Nsukka: University of Nigeria Press.

House of Commons (2014). Contracting out public services to the private sector. London: Public Accounts Committee.

Ibok, E. E. (2014). "Local governance and service delivery in Nigeria.” Caribbean Journal of Science and Technology, 2 536-541.

Iwundu, I. (2012). Due process and executive decisions in local government system in Nigeria. Ikenga International Journal of Institute of African Studies, 14(1 \& 2), September. https://doi.org/10.1111/j.1467-6451.2010.00430.x

Khemani, K. (2001) Fiscal federalism and service delivery in Nigeria: The role of States and Local Governments. Washington, D. C.: World Bank.

Levin, J., \& Tadelis, S. ( 2010). Contracting for government services: Theory and evidence from U.S. cities. Journal of Industrial Economics LVIII, (3), September.

Marlin, J. T. (1984). Privatisation of local government activities: Lessons from Japan. London: Aims of Industry.

Muktar, S. A., \& Abdu, J. B. (2014). Due process and local government administration in Nigeria: A conceptual relationship. Journal of VLSI and Signal Processing, 4(1), January, 26-30. https://doi.org/10.9790/4200-04122630

Nwofia, J. E. (2017). Due process in public procurement as anti-corruption strategy in Nigerian local government. Journal of International and Public Affairs, 1(1), 24-33.

Odalonu, H. P. (2015). Challenges confronting local government Administration in efficient and effective service delivery: The Nigerian experience. International Journal of Public Administration and Management Research, 2(5), March, 12-22.

OECD (2011). Contracting out government functions and services in post-conflict and fragile states: Examples from the health sector in Latin America and the Caribbean. OECD Partnership for Democratic Governance workshop discussion paper

Ohio Civil Service Employees Association (2013). Fighting contracting out: A resource guide. Washington DC: OCSEA.

Pava, M. L. (2009). Financial agency theory. Encyclopedia Britannica, Inc. https://www.britannica.com/topic/financial-agency-theory (assessed on 12/04/2017)

Tolu, L. E., \& Olagunjoye, A. (2010). Local government, corruption and democracy in Nigeria. Journal of sustainable Development in Africa, 12(5), 227-236

United Nations Human Settlements Program (2015). The Challenge of Local Government Financing in Developing Countries. Nairobi: UN-HABITAT.

Uzuegbunam, A. O., \& Nwofia, J. E. (2014). Ethno-communal conflict and the local government system in Nigeria: A desideratum of peace building. Journal of Scientific Research \& Reports, 3(10), 1403-1420. https://doi.org/10.9734/JSRR/2014/9061

World Bank (2004). World development report, 2004 overview: Making services work for poor people.World Bank: Washington D.C.

Yilmaz, S., Beris, Y., \& Serrano-Berthet, R. (2008). Local government discretion and accountability: A diagnostic framework for local governance. Social Development, Local Governance \& Accountability Series Paper No. 113, July.

\section{Copyrights}

Copyright for this article is retained by the author(s), with first publication rights granted to the journal.

This is an open-access article distributed under the terms and conditions of the Creative Commons Attribution license which permits unrestricted use, distribution, and reproduction in any medium, provided the original work is properly cited. 